Annals of Tropical Research 27(2):53-68

( ) LSU, Leyte, Philippines

\title{
Physical and chemical characteristics of two wetlands in Lake Danao Natural Park, Ormoc City
}

\author{
Nadia P. Alfante and Teofanes A. Patindol \\ Department of Forest and Wildlife Management and Conservation, College of \\ Forestry and Natural Resources, Leyte State University, Baybay, Leyte
}

\begin{abstract}
Alfante, N. P. and T. A. Patindol. 2005.Physical and chemical characteristics of two wetlands in Lake Danao Natural Park, Ormoc City. Ann. Trop. Res. 27 (2):53-68

The study was conducted to characterize the wetlands located at Sitio Quinto Limbo and Tasakan in Lake Danao Natural Park, Ormoc City based on some physicochemical parameters.

The two wetlands are generally shallow. Salinity ranged from 0.3 to $0.5 \mathrm{ppt}$ which is characteristic of an oligohaline wetland. Sediment and water were slightly acidic. Concentrations of ammonium ions were lower than the normal value. Levels of nitrate and phosphate ions exceeded the normal value of $1 \mathrm{mg} / \mathrm{L}$ and $0.025 \mathrm{mg} / \mathrm{L}$, respectively.

Lead ion concentrations were generally within the normal range $(10-100 \mathrm{mg} / \mathrm{kg})$. Mean cadmium ion concentration was normal $(0.01-1.0 \mathrm{mg} / \mathrm{kg})$ although in some sites concentrations beyond the normal range were observed.

Based on the findings, it is recommended that conservation program be urgently implemented in the study area to ensure the conservation of the wetlands and their resources.
\end{abstract}

Keywords: wetlands, Lake Danao Natural Park, physico-chemical characteristics, salinity

Correspondence: T. A. Patindol Address: Department of Forest and Wildlife Management and Conservation, College of Forestry and Natural Resources, Leyte State University, Baybay, Leyte 6521-A Philippines. E-mail: tapatindol@yahoo.com Tel. No. (053) 3354210. 
Alfante and Patindol

\section{INTRODUCTION}

Wetlands are areas of marsh, fen, peatland, whether natural or artificial, permanent or temporary, with water that is static or flowing, fresh, brackish or salty, including areas of marine water, the depth of which at low tides does not exceed six meters (RAMSAR, 1997). Wetlands are among the most productive ecosystems in the world, comparable to rainforests and coral reefs (Mitsch and Goooselink, 2000). They are the sources of substantial biodiversity in supporting numerous species from all of the major groups where it protects shorelines, cleanses polluted water, prevents flood and recharges groundwater aquifers (Encyclopedia Brittanica, 2003). In addition, wetlands provide recreational opportunities, aesthetic benefits and sites for research and education.

Generally, wetlands vary widely because of their physical and chemical characters which are affected by several factors such as climate, topography, geology, soil, hydrology and human perturbation. Characterization of wetlands offers better opportunities to gain thorough understanding of their behavior which is necessary in the formulation of a resource conservation program. This study was conducted to characterize the two wetlands located in Sitio Quinto Limbo and Tasakan in Lake Danao Natural Park, Ormoc City. The data generated in this study would be very useful in the formulation of an integrated conservation program for the entire Lake Danao Natural Park.

\section{MATERIALS AND METHODS}

\section{Description of study area}

Lake Danao Natural Park is situated in the highlands of North-Central Leyte, specifically at $10^{\circ} 1^{\prime} 04^{\prime \prime}$ North and $124^{\circ} 42^{\prime} 10^{\prime \prime}$ East and about 18 kilometers northeast of Ormoc City, Leyte, Philippines. It has a total area of 2,193 hectares consisting of an intact forest cover equivalent to about $60 \%$ of its total area, and an exceptionally beautiful inland lake covering an area of 148 hectares. The park is characterized by rolling to rugged terrains with elevation ranging from 480 to $900 \mathrm{~m}$ above sea level. It has gentle slopes 
bisected by gullies and ravines, which slowly drop off into depression (DENR undated).

\section{Description of sampling sites}

Two wetlands associated with Lake Danao Natural Park were considered in the study. These wetlands are the swamp in Sitio Quinto Limbo and the marsh in Sitio Tasakan (Figure 1). Sitio Quinto Limbo swamp is located at $11^{\circ} 03^{\prime} 5.3^{\prime \prime}$ North and $124^{\circ} 4^{\prime} 49.2^{\prime \prime}$ East at an altitude of 706 meters above sea level. It has a total area of 11.302 hectares. Sitio Tasakan marsh is located at $11^{\circ} 5^{\prime} 7.4^{\prime \prime}$ North and 124\%41'5.4" East. It has a total area of 2.304 hectares at an altitude of $703 \mathrm{~m}$ above sea level.

\section{Data collection}

Six sampling stations were randomly established in each wetland for the data collection (Figure 2 and 3). Collection of water and sediment samples was done on the third week of December of 2004. The following physicochemical parameters were determined:

\section{Physical parameters}

Water Temperature $\left({ }^{\circ} \mathrm{C}\right)$. This was determined using a thermometer. The instrument was dipped into the water for two minutes. Water temperature was recorded on a slate board.

Air Temperature $\left({ }^{\circ} \mathrm{C}\right)$. This was determined using a sling psychrometer. Rotating the device with the band up in the air was done. Dry bulb reading corresponds to the air temperature.

Water Depth (m). This was measured using a weighted rope with 1meter calibration and was dropped into the water along the different sampling sites.

Transparency. This was determined using a 20-centimeter diameter standard Secchi disk. The device was lowered into the water to determine the depth at which it disappears.

Salinity. This was determined using the handheld Atago Refractometer. A drop of water was placed on the prism. Reading was recorded. 


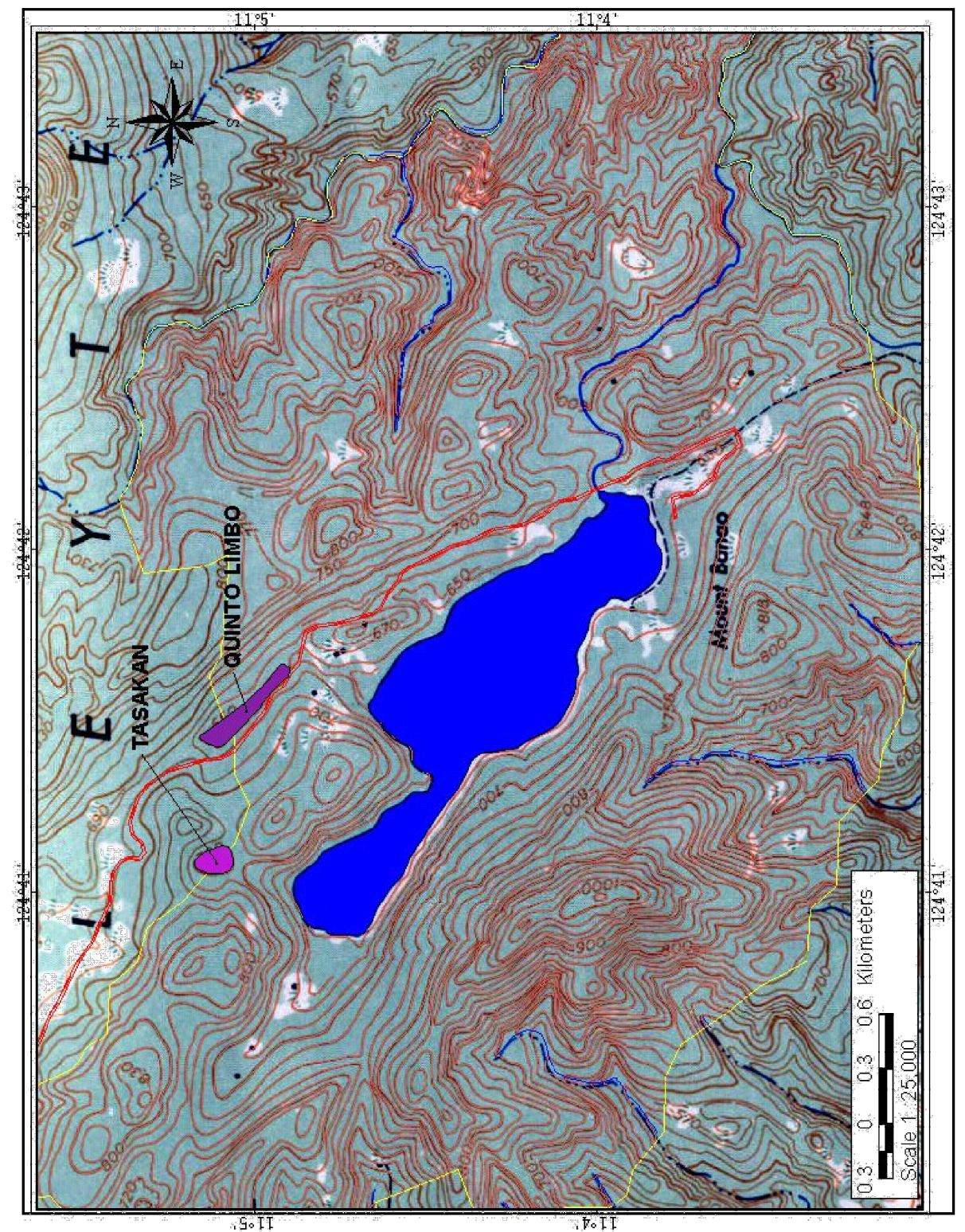

Figure 1. Map of Lake Danao Natural Park, Ormoc City showing the study sites. 


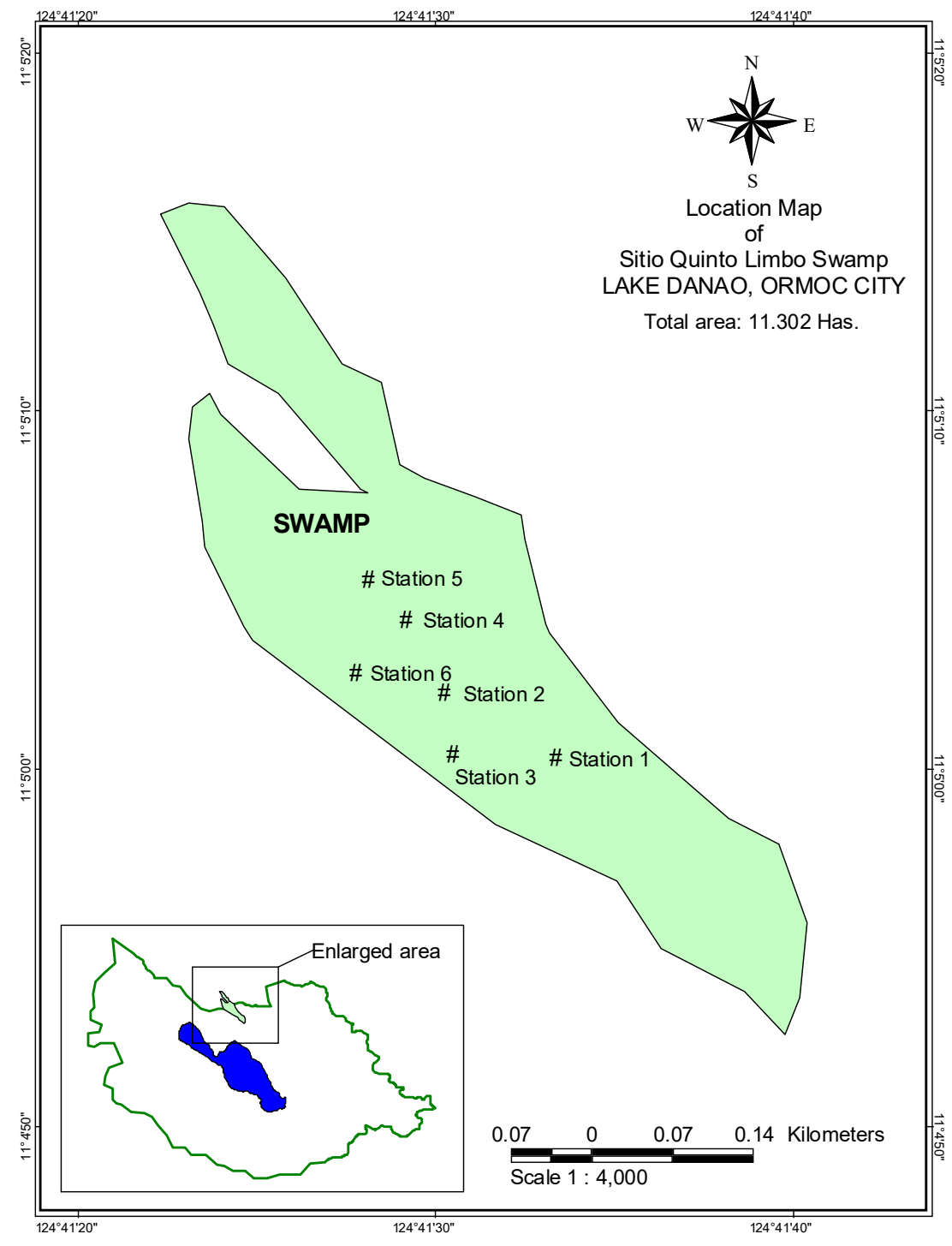

Figure 2. Map of Sitio Quinto Limbo swamp, Lake Danao, Ormoc City showing the sampling points. 


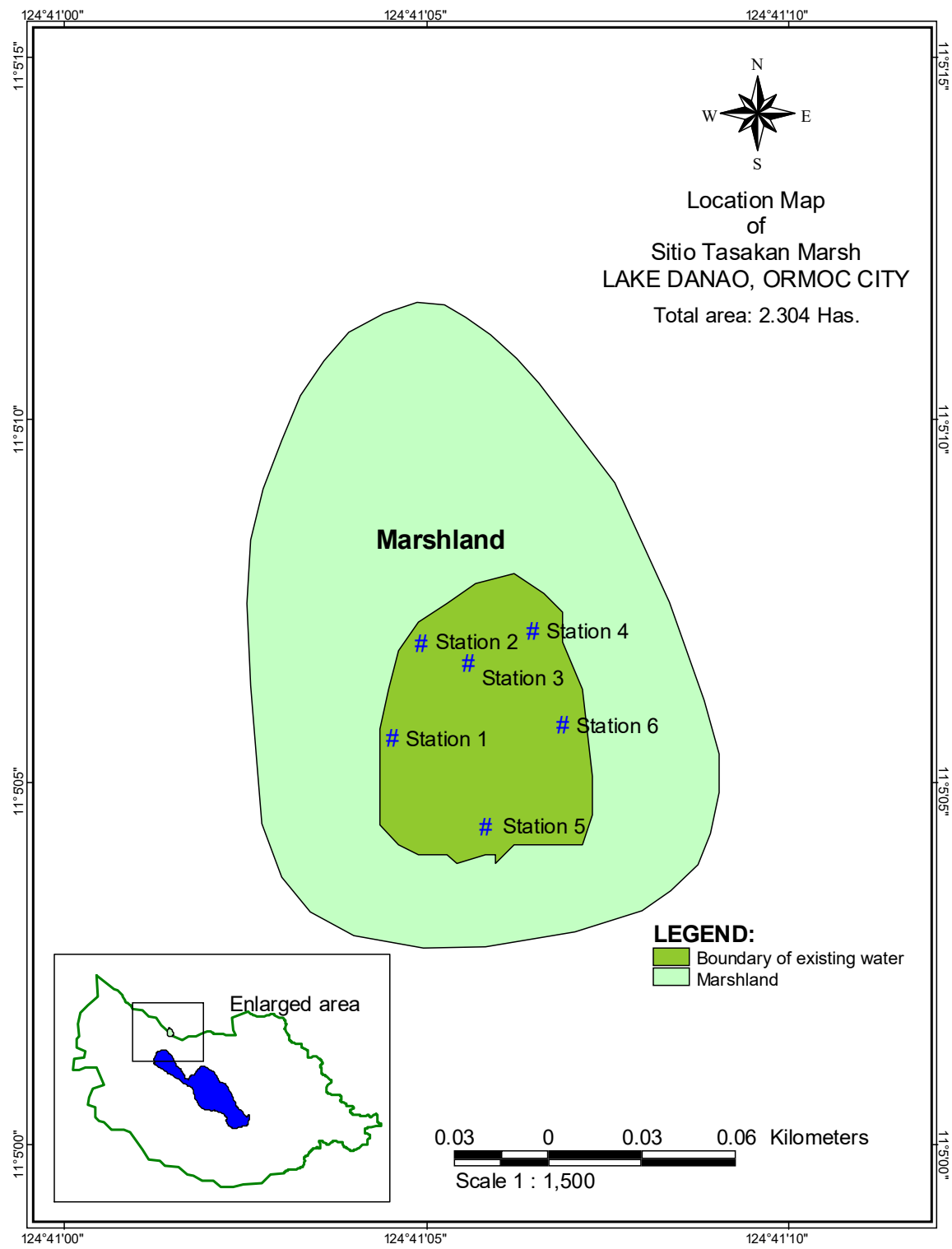

Figure 3. Map of Sitio Tasakan marsh, Lake Danao, Ormoc City showing the sampling points. 


\section{Chemical parameters}

To determine the chemical characteristics of the wetlands, water samples were taken from the two sites and were placed in bottled containers with proper labels. In situ analysis was done. The following chemical parameters were determined using the Merck Limnology Test Kit.

Ammonium (mg/L). $\mathrm{NH}_{4}$ ion concentration in the water was determined using the colorimetric method Aquaquant Ammonium test. Two tubes were filled with $20 \mathrm{ml}$ water samples. One syringe $(2.5 \mathrm{ml})$ of $\mathrm{NH}_{4}-1 \mathrm{~B}$ was added to the inner tube and was mixed. The one level microspoon of $\mathrm{NH}_{4}-2 \mathrm{~B}$ was added, dissolved and set aside for 5 minutes. Finally, 2 drops of $\mathrm{NH}_{4}-3 \mathrm{~B}$ was added and mixed. After 7 minutes, the color change was then compared to the color chart provided with the kit. Each color corresponds to a specific $\mathrm{NH}_{4}$ value.

Nitrate $(\mathrm{mg} / \mathrm{L})$. This was measured using the Microquant Nitrate test. Two tubes containing $20 \mathrm{ml}$ of water sample were prepared. Two microspoons of $\mathrm{NO}_{3}-1 \mathrm{~A}$ was added to the right hand tube. Then, one syringe $(5 \mathrm{ml})$ of $\mathrm{NO}_{3}-2 \mathrm{~A}$ was added to dissolve the $\mathrm{NO}_{3}-1 \mathrm{~A}$. A $1.5 \mathrm{ml}$ of water sample was added and mixed. Finally, $6 \mathrm{ml}$ of the mixed solution was placed on the left hand tube and was allowed to stand for 10 minutes. When the mixture turned red or pink, it was placed on the comparator and held against the light. Each color that matched with the comparator corresponded to specific nitrate value.

Phosphate (mg/L). The Aquaquant Phosphorus test was used; $20 \mathrm{ml}$ of water samples were placed in the two test tubes. Ten drops of P-1A were added in the sample tube closest to the tester and was mixed. One level microspoon of $\mathrm{P}_{2}$-A was also added to the mixture. It was shaken to dissolve. The solution was left to stand for 2 minutes to follow full color development. Color of the sample was matched with the color chart provided.

Water $\mathrm{pH}$. This was determined using a $\mathrm{pH}$ paper. It was dipped into the water for 2 seconds and was compared to the comparator chart for $\mathrm{pH}$ value.

\section{Collection and preparation of sediment samples}

In each sampling site, soil samples were collected using a core sampler. This was done by inserting a modified hand corer with a diameter of $5 \mathrm{~cm}$ into 
the ground/sediments. Sediment samples were placed in labeled containers. These were air dried, and then pulverized using $0.40 \mu \mathrm{m}$ US Standard Testing Sieve for nutrient analysis and $20 \mu \mathrm{m}$ for heavy metal analysis. The processed samples were brought to the Department of Agronomy and Soil Science at Leyte State University (LSU) for nutrient analysis particularly organic matter and phosphorus. Duplicate samples were brought to the Central Analytical Service Laboratory (CASL) of LSU for the analysis of $\mathrm{Pb}$ and $\mathrm{Cd}$ content.

\section{Determination of $\mathrm{Pb}$ and $\mathrm{Cd}$ in soil sediments}

The soil sediments were prepared using the methods of Salas et al. (1998) for total $\mathrm{Pb}$ and $\mathrm{Cd}$ analyses. This invovled placing exactly $5 \mathrm{~g}$ of soil in a $30 \mathrm{ml}$ glass beaker. Fifty $(50 \mathrm{ml})$ of the acid mixture composed of nitric acid, hydrochloric acid and sulfuric acid at a ratio of 10:4:1 was then added. The mixture was heated at $170{ }^{\circ} \mathrm{C}$ on a hot plate inside a fume hood until the solution turned clear. Thereafter, the mixture was evaporated to dryness and allowed to cool to room temperature. After cooling, the inner side of the beaker was washed with distilled water and the solution was decanted to a filtering funnel fitted with Whatman \# 42 filter paper. The filtrate was cooled and diluted to $250 \mathrm{ml}$ with deionized water and the absorbance of the resulting solution was read using Atomic Absorption Spectrophotometer (AAS). The wavelength used for lead was $217.0 \mathrm{~nm}$ while $228.8 \mathrm{~nm}$ for cadmium. All instrument readings were converted into metal concentration using the equation:

$$
\mathrm{C}=\mathrm{RV} / \mathrm{W}
$$

where:

$$
\begin{aligned}
& \mathrm{C}=\text { concentration of the metal being analyzed in } \mathrm{mg} / \mathrm{kg} \text { soil } \\
& \mathrm{R}=\mathrm{AAS} \text { reading in } \mathrm{ppm} \\
& \mathrm{V}=\text { volume of the soil sample in } \mathrm{g} \\
& \mathrm{W}=\text { weight of the soil samples in } \mathrm{g}
\end{aligned}
$$




\section{RESULTS AND DISCUSSION}

\section{Physico-chemical parameters}

Table 1 shows the results of the analysis of the physico-chemical parameters of the two wetlands. Sitio Quinto Limbo swamp had a mean depth of $1.87 \mathrm{~m}$ ranging from 1.61 to 2.29 meters. Sitio Tasakan ranged in depth from 0.75 to 0.86 meters with an average of $0.80 \mathrm{~m}$. This means that the water table during the time of data collection was relatively low. According to the local residents, water levels in the two wetlands are fluctuating from time to time depending upon the season of the year.

The mean transparency in Sitio Quinto Limbo swamp was $0.94 \mathrm{~m}$. This low transparency could be due to suspended solids, either decayed organic matter or silt that trapped the light passing through. In Tasakan marsh, transparency was not measured because the water was too shallow and sediments were easily stirred up causing the water to become turbid. Unlike in Sitio Quinto Limbo where the water was relatively deep, making use of nonmotorized boat was possible during the data collection.

In Sitio Quinto Limbo, there was a slight difference between the mean air temperature $\left(25.1^{\circ} \mathrm{C}\right)$ and the water temperature $\left(27.1^{\circ} \mathrm{C}\right)$. The relatively high temperature of the water could be attributed to the massive growth of an introduced plant Pistia sp. that during decomposition bacteria used up oxygen, thus making the water warmer. In Sitio Tasakan, the mean air $\left(26.4{ }^{\circ} \mathrm{C}\right)$ and water temperatures $\left(26.4{ }^{\circ} \mathrm{C}\right)$ were the same. This wetland, being a marsh, lacks tree vegetation. Thus it is directly exposed to the sun which could explain the similarity in temperature.

Salinity of the two wetlands ranged from 0.3 to $0.5 \mathrm{ppt}$., which is characteristic of an oligohaline wetland based on the study of Espinosa and Warner (2004). The study pointed out that a wetland with salinity within 0-10 ppt is considered as oligohaline wetland. The amount of salt in a water body is the major contributing factor in characterizing this kind of an ecosystem. 
Table 1. Physico-chemical parameters of Quinto LImbo and Tasakan wetlands, Lake Danao Nature Park, Ormoc City

\begin{tabular}{lllll}
\hline Parameters & \multicolumn{2}{c}{ Quinto Limbo } & \multicolumn{2}{c}{ Tasakan } \\
& Mean & Range & Mean & Range \\
\hline Depth $(\mathrm{m})$ & 1.87 & $161-2.29$ & 0.80 & $0.75-0.86$ \\
Transparency $(\mathrm{m})$ & 0.94 & $0.82-0.97$ & nd & nd \\
Temperature $\left({ }^{0} \mathrm{C}\right)$ Air & 25.1 & $23.4-26.0$ & 26.4 & $23.0-30.0$ \\
Temperature $\left({ }^{0} \mathrm{C}\right)$ Water & 27.1 & $25.5-29.1$ & 26.4 & $24.0-29.0$ \\
Salinity $(\mathrm{ppt})$ & nd & $0.3-0.5$ & nd & $0.3-0.5$ \\
pH (Water) & nd & $5-6$ & nd & $5-6$ \\
pH (Soil) & 5.45 & $2.7-6.05$ & 6.025 & $5.1-6.8$ \\
Ammonia(mg/L) & nd & $0-0.5$ & nd & $0-0.25$ \\
Phosphate $(\mathrm{mg} / \mathrm{L})$ & nd & $0.015-0.03$ & nd & $0.015-0.03$ \\
Nitrate $(\mathrm{mg} / \mathrm{L})$ & nd & $0-5$ & nd & $0-10$ \\
$\%$ OM & 51.17 & $8.587-116.909$ & 16.974 & $4.084-36.162$ \\
Phosphorus $(\mathrm{ppm})$ & 0.226 & $0.042-0.845$ & 1.913 & $0.268-3.344$ \\
\hline
\end{tabular}

nd - not determined

Water $\mathrm{pH}$ of the two wetlands ranged from 5 to 6 , which is acidic. In terms of sediment acidity, both sites were acidic but Quinto Limbo had more sampling sites that were acidic than Tasakan. This could be primarily due to the abundant decaying organic matter in Quinto Limbo. During organic matter decomposition, carbon dioxide is produced that reacts with water to form a weak acid in the form of carbonic acid. Another reason was acidic precipitation that flows through soils in watersheds that releases Al from the soils into lakes and streams (Johnson, 2004). The bottom sediments could also be anoxic so hydrogen sulfide was present in high concentration that can make the sediments acidic. According to a local resident, two years ago there were fish kills in Sitio Quinto Limbo swamp. The fish kills could be attributed to lower $\mathrm{pH}$ values of sediment and water. Based on the study of Hesthagen (2000), mortality of Atlantic salmon and brown trout in Southwestern Norway was due to the low $\mathrm{pH}$.

For ammonium, phosphate and nitrate determination; colorimetric method was used; hence values were given in range. Sitio Tasakan marsh contained $0-0.25 \mathrm{mg} / \mathrm{L}$ of ammonium while Quinto Limbo contained $0-0.5 \mathrm{mg} / \mathrm{L}$. These 
values are considerably low. According to Welch (1952), values below $1 \mathrm{mg} /$ L are generally normal. Ammonium persists in small quantities according to (Wetzel, 1983) although it is a major excretory product of aquatic animals because ammonium ion is rapidly taken up by phytoplankton and other aquatic animals. However in Sitio Quinto Limbo, values ranged from $0-0.5 \mathrm{mg} / \mathrm{L}$, and this could be due to the organic matter at the bottom sediments. Values as small as $0.5 \mathrm{mg} / \mathrm{L}$ are known to slightly inhibit photosynthesis in species of blue green algae (Horne and Goldman, 1983). .

According to Horne and Goldman (1983), $\mathrm{NO}_{3}$ found in lakes and rivers are not toxic in quantities up to $1 \mathrm{mg} / \mathrm{L}$. Concentrations of nitrate in Sitio Tasakan and Quinto Limbo were 0-10 mg/L and 1-5 mg/L, respectively. Therefore, the levels could be considered toxic to aquatic plants and animals. Together with $\mathrm{P}_{2} \mathrm{NO}_{3}$ in excess amount can accelerate eutrophication, causing dramatic increases in aquatic plant growth and changes in the types of plants that live in the water body which consequently affects dissolved oxygen, temperature and other indicators. It can also cause hypoxia and become toxic to warm blooded animals at higher concentrations (0-10 mg/L) (Welch, 1952; Wetzel 1983; Horne and Goldman, 1983).

Excess $\mathrm{NO}_{3}$ in two wetlands studied could be due to run off from fertilized croplands within the same catchment primarily devoted to cabbage and other high value crops. The presence of water buffaloes within the vicinity of the sampling sites could also explain high $\mathrm{NO}_{3}$ levels. Manure run off contains high levels of nitrate.

Results showed that $\mathrm{PO}_{4}$ levels in the water $(0.015-0.030 \mathrm{mg} / \mathrm{L})$ for both wetlands exceeded the normal value $(0.025 \mathrm{mg} / \mathrm{L})$ given by the U.S Environmental Protection Agency (1988). This could be due to human activities such as the use of detergent soap, which contains $\mathrm{P}$ and inputs of domestic sewage and fertilizers. This has resulted to a massive growth of Pistia sp. especially in the Sitio Quinto Limbo swamp.

$P$ in sediments of the two sites considerably varied. Sitio Quinto Limbo had a mean of $0.226 \mathrm{ppm}$ while Sitio Tasakan averaged $1.913 \mathrm{ppm}$. The high amount of P in Tasakan must have come from surface run-off of the surrounding cultivated areas, which are principally devoted to high-value crops like cabbage. Considering that there was not much massive growth of aquatic plants in this marsh, much of the phosphorus was left to accumulate in deep sediments. 
As regard the organic matter content of sediment, Quinto Limbo contained about $51 \%$ while Tasakan, about $16 \%$ only. Quinto Limbo wetland, being a swamp supports a massive growth of vegetation particularly on the littoral zones. Plant litter accumulate and naturally decompose through time. This explains the high amount of organic matter that accumulated in the bottom sediments in Quinto Limbo.

\section{Traces of heavy metals}

In this study, sediments were collected at 10:15 AM until 1:32 PM. The weather was fair and windy with isolated rain showers. Sediments were collected up to $15 \mathrm{~cm}$ depth from the surface layer of the bottom soil.

$\mathrm{Pb}$ and $\mathrm{Cd}$ concentrations in the two sites are presented in Table $2 . \mathrm{Pb}$ concentrations of Tasakan and Quinto Limbo were 37.5 and $29.08 \mathrm{mg} / \mathrm{kg}$, respectively. These values are within the normal range of $10-100 \mathrm{mg} / \mathrm{kg}$ (Ross, 1994). The accumulation of $\mathrm{Pb}$ in the two wetlands could be due to the weathering of the parent rock material. According to Pain (1995), lead maybe deposited in two forms; either wet or dry deposition. Wet deposition results from the incorporation of particles into water droplets in the clouds or the accumulation of particles by falling precipitation. Dry deposition, on the other hand, is either by gravitational settling of large particles $(710 \mu \mathrm{m})$ or the impaction of all sizes (especially smaller particles).

$\mathrm{Pb}$ in soils results mainly from dry and wet deposition of atmospheric lead, particularly due to emission sources and the disposal of sewage sludge, often onto agricultural land. Based on the study of McGowen and Basta, (1995) distribution of Cu and Pd were mostly concentrated in the upper layer of the soil (0-10 cm). Zimmerman (1986) as cited by (Ross, 1994), found that solubility of $\mathrm{Pb}$ in deposition increased significantly when rain $\mathrm{pH}$ decreased from 6.4 to 3.4. Cd and $\mathrm{Pb}$ showed peaks in concentration from February to April and became lower in July to September (Ross, 1994). In Sitio Tasakan levels of $\mathrm{Pb}$ reached up to $40.00 \mathrm{mg} / \mathrm{kg}$ since the area was open with less vegetation so deposition of lead particles was easier. Unlike in Sitio Quito Limbo swamp the levels of $\mathrm{Pb}$ was only $22.00-31.00 \mathrm{mg} / \mathrm{kg}$, because there was a massive growth of vegetation so $\mathrm{Pb}$ particles were not easily deposited in sediments. It was reported by Lubberding et al, (2004) that Pistia sp. helps removes $\mathrm{Zn}$ and $\mathrm{Pb}$ in a wetland by absorbing it. 
Table 2. Levels of $\mathrm{Pb}$ and $\mathrm{Cd}$ in Sitio Quinto Limbo and Tasakan wetlands

\begin{tabular}{rcc}
\hline Wetland & Total $\mathrm{Pb}(\mathrm{mg} / \mathrm{kg})$ & Total Cd $(\mathrm{mg} / \mathrm{kg})$ \\
\hline Sitio Tasakan & & \\
Sample 1 & 38.00 & 0.40 \\
Sample 2 & 40.00 & 1.30 \\
Sample 3 & 36.50 & 0.80 \\
Sample 4 & 34.50 & 0.90 \\
Sample 5 & 37.00 & 1.10 \\
Sample 6 & 39.50 & 1.40 \\
Mean & 37.58 & 0.98 \\
Sitio Quinto Limbo & & \\
Sample 1 & 22.00 & 1.75 \\
Sample 2 & 26.00 & 1.20 \\
Sample 3 & 28.50 & 0.85 \\
Sample 4 & 32.50 & 0.95 \\
Sample 5 & 31.00 & 0.40 \\
Sample 6 & 34.50 & 0.40 \\
Mean & 29.08 & 0.92 \\
\hline
\end{tabular}

For $\mathrm{Cd}$, on the other hand, results showed that $\mathrm{Cd}$ mean concentration was $0.98 \mathrm{mg} / \mathrm{kg}$ for Tasakan and $0.92 \mathrm{mg} / \mathrm{kg}$ for Quinto Limbo. There were sites containing values beyond the normal range of $0.01-1 \mathrm{mg} / \mathrm{kg}$ (Ross, 1994). Another study (Ross, 1994) reveals that $3-8 \mathrm{mg} / \mathrm{kg}$ of Cd in the soil is considered toxic to the environment. $\mathrm{Cd}$ concentration was low because collection of samples was only up to $15 \mathrm{~cm}$ depth. Another reason was the percentage of organic matter which was high and soil which was acidic. In the study of McGowen and Basta (1995), the distribution of Cd and Zn within soil profiles was correlated with the organic matter of the soil, suggesting that metal-organic complexes are responsible for their movement to lower depths (20-30 cm). Dumontet et al, (1990) and Weider (1990), as cited by McGowen and Basta (1995) presented evidences for strong adsorption and retention of metals by peat. Peat substrates have also been used as cleaning agents to remove metals for contaminated wastes. The acidity of the soil also has tendency to decrease the retention of metals by oxide fractions due to $\mathrm{pH}$ values below point of zero charge of these oxide fractions. Brummer and Hermis (1983), as cited by Ross (1994), reported that retention and mobility 
of $\mathrm{Cd}$ and $\mathrm{Zn}$ were related to soil $\mathrm{pH}$. These metals are more soluble at $\mathrm{pH} 4-$ 5. They are relatively more mobile under acid, oxidizing conditions and are retained very strongly under alkaline and reducing conditions (Plaut and Kaiswell, (1983) as cited by Ross (1994).

\section{CONCLUSIONS AND RECOMMENDATIONS}

\section{Conclusions}

Based on the results of the study, the following conclusions were drawn.

1. Quinto Limbo swamp and Tasakan marsh are generally shallow, acidic and with low salinity.

2. Ammonium levels of the two wetlands are considerably low but the concentration of nitrates is high which can be toxic to aquatic plants and animals. Phosphate in water for both wetlands exceeds the normal range value. Sediments contain considerable amount of P particularly in Tasakan where intensification in farming is currently being practiced.

3. The Pb concentration of the two wetlands is generally within the normal range. Cd concentration of the two sites is beyond the normal range, which can therefore be considered toxic to the environment.

4. Quinto Limbo contains high amount of organic matter because it supports a massive growth of vegetation particularly on the littoral zones.

\section{Recommendations}

1. Since physico-chemical characteristics are easily affected by changes in environmental factors, one year monthly monitoring of the two wetlands should be done taking note on the following:

a. Standard methods in water analysis should be done to determine the specific value.

b. The amount of dissolved oxygen should also be measured.

c. In dealing with heavy metals, water and plant samples should be analyzed to compare the results.

2. The study reveals that some elements, such as nitrate and phosphate, 
exceed the normal ranges which can be detrimental to the overall health of these wetlands. This can be linked directly to the current farming practices in the surrounding areas. This calls for a more in-depth analysis on the effect of current farming practices on these wetlands in order to better understand the dynamics of the system particularly on its ability to cleanse polluted water.

3 . In the meantime that the characteristics of the two wetlands are not yet fully understood, their potential as ecotourism sites should be harnessed. These wetlands are ideal for recreation where one can take photographs of wild life and vegetation and with that there will be extra income for the residents. Ecotourism should form part of an integrated conservation program that addresses the economic well-being of the local population and the long termterm sustainability of these wetlands.

\section{ACKNOWLEDGMENT}

This research was party funded by ALO's Community-based Watershed Management Support Project under FARMI of the Leyte State University. The authors would like to thank Dr. Candelario Calibo, Dr. Pastor P. Garcia, and Ms. Analyn M. Mazo for their valuable comments on the draft of this paper.

\section{LITERATURE CITED}

ANDREWS, W. 1987. Investigating Aquatic Ecosystems, 2nd edition. Prentice-Hall Inc., Canada.

BARBIER, E.B., M. ACREMAN, and D. KNOWLER. 1997. Economic valuation of wetlands: a guide for policy makers and planners. RAMSAR Convention Bureau, Gland Switzerland.

DEPARTMENT OF ENVIRONMENT AND NATURAL RESOURCES(DENR). Undated. Lake Danao Natural Park Information Brochure.

ENCYCLOPEDIA BRITTANICA. 2003. Wetland. Brittanica Inc., North Sidney, Australia. 
ESPINOSA, F.C. and BARREY G. WARNER. 2004. Ecosystem characteristics and management consideration for coastal wetlands in Mexico. Hydrobiologia 511:233-254

HORNE, A.J. and CHARLES R. GOLDMAN, 1983. Limnology (ed), Mc Graw Hill, Inc. USA.

JOHNSON,G.V. 2004. Causes of Soil Acidity. (http://www..soiltesting.edu/Extn_.)

LUBBERDING, H.J., LEMAN, M., DENNY, P., GIJZEN, H. 2004. Zinc Removal by the Aquatic Macrophyte Pistia stratiotes http://www.ucd.ie/ wetland/wethome.htm

MCGOWEN, P. and BASTA, L. 1995. Lead and Cadmium in Soils. In: Heavy Metals Release in Soils, Selim, H.M. and Sparks D.C. (ed.) CRD Press, Florida.

MISTCH, W.J. and J.G. GOOSELINK. 2000. Wetlands 3rd edition. Von Nostran Reinhold, New York. pp. 31-49, 81-90.

PAIN, D.J. 1995. Lead in the Environment. In: Handbook of Ecotoxicology,David J. Hoffman, Barnett A. Rattner, G. Allen Burton, Jr. and John Cairns, Jr. (ed.) CRC Press, Inc. USA. pp. 356

RAMSAR Convention. 1997 Values of Wetlands, Tehran, Iran.

ROSS, S. M. 1994. Toxic Metals: Fate, Distribution in Contaminated Ecosystems. In:Toxic Metals Soil-Plants Systems. Sheila M. Ross (ed.) John Wiley and Sons Ltd., New York. pp. 189-241

SALAS, F.M., S. GOTO., T. IGARASHI, H. MSUJIMA, and K. KUMAZAWA. 1998. Forms and distribution of heavy metals in soils long term applied with sewage sludge. ISSAAS. 4:633-68

TURNER, K. and T. JONES. 1990. Wetlands: Market and Interventions Failures, Case Studies. Earthscan Publications Unlimited.

U.S.A Environmental Protection Agency 1988. Phosphorus in lakes and Reservoirs (http.//webpages.character.net/ kwingwerden/erhs/aquarium/phosphate.htm)

WELCH. P.S. 1952. Limnology 2nd ed. Mc Graw Hill Book Company, Inc., USA

WETZEL, R.G. 1983. Limnology, 3rd edition. Saunders Publishing, USA. 